ARTICLE

https://doi.org/10.1038/s41467-019-08847-1

\title{
Krill faecal pellets drive hidden pulses of particulate organic carbon in the marginal ice zone
}

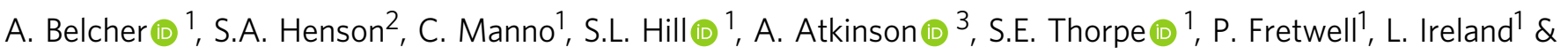 \\ G.A. Tarling ${ }^{1}$
}

The biological carbon pump drives a flux of particulate organic carbon (POC) through the ocean and affects atmospheric levels of carbon dioxide. Short term, episodic flux events are hard to capture with current observational techniques and may thus be underrepresented in POC flux estimates. We model the potential hidden flux of POC originating from Antarctic krill, whose swarming behaviour could result in a major conduit of carbon to depth through their rapid exploitation of phytoplankton blooms and bulk egestion of rapidly sinking faecal pellets (FPs). Our model results suggest a seasonal krill FP export flux of 0.039 GT C across the Southern Ocean marginal ice zone, corresponding to 17-61\% (mean 35\%) of current satellite-derived export estimates for this zone. The magnitude of our conservatively estimated flux highlights the important role of large, swarming macrozooplankton in POC export and, the need to incorporate such processes more mechanistically to improve model projections.

\footnotetext{
${ }^{1}$ British Antarctic Survey, Cambridge CB3 OET, UK. ${ }^{2}$ National Oceanography Centre, Southampton SO14 3ZH, UK. ${ }^{3}$ Plymouth Marine Laboratory, Prospect Place, The Hoe, Plymouth PL1 3DH, UK. Correspondence and requests for materials should be addressed to A.B. (email: annbel@bas.ac.uk)
} 
$\mathrm{T}$ he flux of particulate organic carbon (POC) through the ocean via the biological carbon pump (BCP) is tightly coupled to atmospheric levels of carbon dioxide $\left(\mathrm{CO}_{2}\right)^{1}$. However, limited observations result in poorly constrained models of POC flux, particularly in the Southern Ocean. The rate at which the flux of sinking POC declines with depth can be quantified and modelled by the attenuation rate. However, studies of POC flux attenuation struggle to capture episodic, intense, or localised export events because of limited sampling and the patchy nature of such events in time and space. Hence these events may be under-represented in flux estimates. These intense events may be particularly efficient in transferring POC to the ocean's interior as they may be driven by high primary production, and subsequent faecal pellet production by consumers, which overwhelms the grazing capacity of the community of detrital feeders $^{2-4}$. In this study, we focus on the POC flux generated by the faecal pellets of Antarctic krill.

Antarctic krill (Euphausia superba) comprise the highest individual species biomass of any metazoan in the Southern Ocean; swarms can extend over areas of $\sim 100 \mathrm{~km}^{25}$. Krill are thus an important part of Southern Ocean ecosystems, forming a key link between primary producers and higher trophic levels ${ }^{6}$. Being one of the largest epipelagic crustaceans, krill also produce large faecal pellets (FPs), which sink at speeds of hundreds of metres per day 2,4 , making them important agents in carbon export. In this way, carbon that originated in the atmosphere is transferred to the deep sea where it can be sequestered for periods of centuries or more ${ }^{7}$. Krill FPs have been found in high numbers in sediment traps in both the upper and deep ocean ${ }^{8-10}$. Although some carbon from krill FPs may be retained in the upper mixed layer through coprorhexy, coprophagy, and remineralisation ${ }^{11,12}$, two combining factors, namely the rapid sinking speeds of krill FPs and the occurrence of krill in large swarms, mean that atypically large and episodic krill FP fluxes can occur in certain regions at certain times of the year $8,10,13$.

Measuring the flux of POC in situ at various depths in the water column is challenging, resulting in relatively poor spatial and temporal coverage of measurements when compared to more easily measureable ocean variables such as temperature or nitrate. Empirically derived models for POC flux that utilise limited in situ snapshot POC flux measurements may not capture episodic fluxes, such as those driven by krill swarms, and likely underestimate the carbon flux in regions of high krill density. This is especially true for models with a spatially and temporally invariant attenuation rate (typically Martin's $b$ value ${ }^{14}$ ). This means that individual krill swarms will not be resolved either in time or space. Without mechanistic representation of the FP flux associated with krill swarms, biogeochemical models may not make accurate projections of the contribution of the Southern Ocean to global carbon export.

Antarctic krill have a life cycle strongly tied to seasonal sea ice, which provides nursery areas for the larvae ${ }^{15}$ and can enhance local primary production as it melts, providing rich grazing grounds ${ }^{16,17}$. The role of the marginal ice zone (MIZ; 15-80\% ice cover $^{18}$ ) as a feeding ground for high densities of krill ${ }^{19}$, and the resulting high FP fluxes and low attenuation rates of sinking POC, suggest that the MIZ may be an area of significant POC export in the Southern Ocean ${ }^{20}, 21$. However, particle flux measurements are even more limited in the MIZ (in part due to the difficulties of sampling in sea ice) and, as such, the potential contribution of krill FPs in the MIZ to Southern Ocean export flux has yet to be fully quantified. Additionally, the patchy distribution of krill biomass ${ }^{22}$ may mean that episodic events are poorly represented in many biogeochemical sampling campaigns. The combination of these factors mean that there are few observational data capturing these potentially large krill FP fluxes
(Supplementary Table 1). As empirical algorithms to estimate global export generally rely on extrapolation of datasets of in situ measurements ${ }^{23-25}$, these episodic, but recurrent, krill FP fluxes are likely to be omitted, or at least under-represented, in Southern Ocean flux estimates.

We previously measured high krill FP fluxes and low attenuation rates in the MIZ of the South Orkney Islands ${ }^{2}$, and a small number of other studies have also encountered large fluxes of krill FP associated with low attenuation rates through the upper mesopelagic ${ }^{8,11}, 20,26$. We hypothesise that, where krill densities are high in the MIZ, they will drive large FP fluxes such that the MIZ accounts for a substantial component of the total POC export in the Southern Ocean. To assess the contribution of krill FP to the BCP, we develop an empirical model to make first order estimates of this flux based on spatially-discrete krill density data over the past century (KRILLBASE ${ }^{27}$ ) and in situ measurements of krill FP attenuation in the MIZ of the Southern Ocean. We estimate that the seasonal flux of krill FPs at $100 \mathrm{~m}$ across the MIZ of the Southern Ocean can be large, and is equivalent to $17-61 \%$ of satellite-derived estimates of total carbon flux at this depth. These results highlight that krill FPs are an important contributor to carbon flux and yet they are not mechanistically represented in global biogeochemical models, which restricts our ability to predict future changes to the BCP.

\section{Results}

Krill faecal pellet production and export. The total seasonal krill FPP over the MIZ region is estimated to be 0.065 GT C (ranging from 173 to $2427 \mathrm{mg} \mathrm{C} \mathrm{m}^{-2}$ over the season, with a mean of $786 \mathrm{mg} \mathrm{m}^{-2}$ ). FPP is highest in the Scotia-Weddell Sea area during the period 24 December-06 January (Fig. 1). This area, downstream of the Antarctic Peninsula, supports some of the highest krill densities in the Southern Ocean ${ }^{15}, 27,28$.

We conservatively estimate the export flux of krill FP carbon at $100 \mathrm{~m}\left(\mathrm{FP}_{100}\right)$ based on the above predicted FPP and on a Martin type ${ }^{14}$ attenuation curve with an attenuation coefficient of 0.32 (the median of literature estimates of krill FP attenuation valid for our region $^{2,8,9,11,12,20}$. Averaged over the entire MIZ area $\left(\mathrm{FP}_{100, \mathrm{MIZ}}\right)$, highest FP export fluxes (104 $\mathrm{mg} \mathrm{C} \mathrm{m}^{-2} \mathrm{~d}^{-1}$ ) occur during the period 24 December-06 January. The total seasonal export of krill FP is highest in the Scotia and Weddell seas (peaking at $80 \mathrm{~g} \mathrm{C} \mathrm{m}^{-2}$ in the MIZ region -35 to $\left.-40^{\circ} \mathrm{E}\right)$. Summed over the productive season, we estimate the total export of krill FP at $100 \mathrm{~m}$ in the MIZ $\left(\mathrm{FP}_{100, \text { SEA }}\right)$ to be 0.039 GT C (Table 1).

Model comparisons. We compare our estimate of krill FP export to total POC export from a number of studies ${ }^{23-25}$ that apply empirical algorithms for carbon export to satellite-derived primary productivity data (Table 1). If we assume that these algorithms correctly estimate the POC export in the MIZ, krill FP export could make up $17-61 \%$ (mean 35\%, median 32\%) of total seasonal POC export in the region south of the maximum MIZ extent (Table 1). Additionally, we compare our FP export estimates to three POC export models specific to the Southern Ocean (Table 1), which utilise nutrient and hydrographic data to constrain model parameters and budgets ${ }^{29-31}$ (see methods). The estimate of POC export south of $50^{\circ} \mathrm{S}$ by Schlitzer et al. $(2002)^{30}$ is much higher than other estimates, likely in part due to the inclusion of highly productive coastal waters off South America, and is therefore not used for further comparison. Based on the models of Primeau et al. (2013) and MacCready et al. (2001), which offer the best coverage of the Southern Ocean region analysed here, krill FP fluxes are 13-18\% of the total annual POC export flux, compared to $14-43 \%$ for satellite-derived estimates for the region south of $60{ }^{\circ} \mathrm{S}$ (Table 1). These percentage 

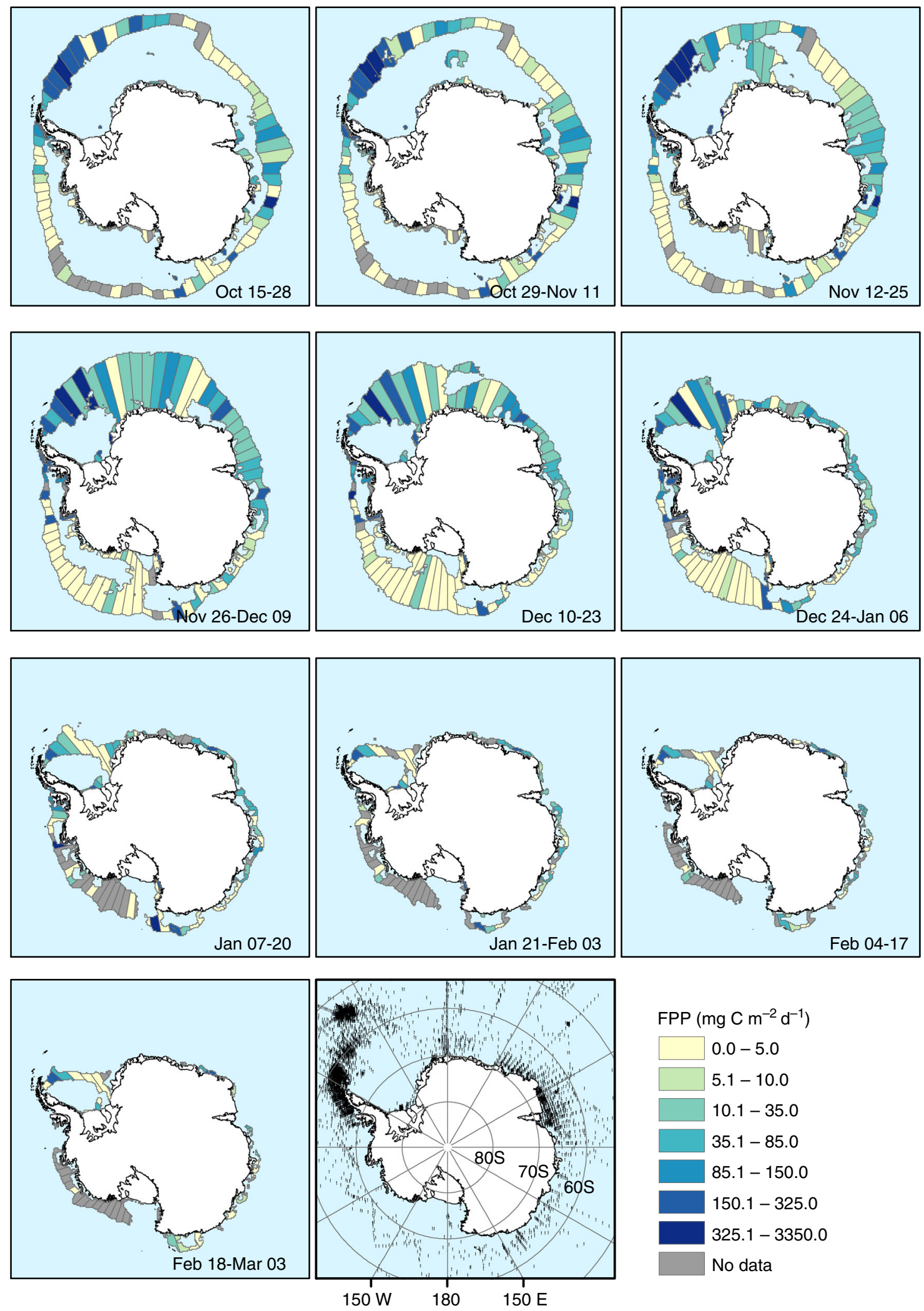

Fig. 1 Estimated krill faecal pellet production (FPP) in the marginal ice zone, Antarctica. The marginal ice zone, from fortnightly sea ice concentration data (15-80\% ice cover), is divided into $5^{\circ}$ zonal cells, and is coloured by FPP ( $\mathrm{mg} \mathrm{C} \mathrm{m}^{-2} \mathrm{~d}^{-1}$ ) based on krill density measurements from KRILLBASE (black dots) and literature krill FP production rates. Regions of the marginal ice zone where no KRILLBASE records occurred are coloured in grey. The Antarctic coastline was obtained from the SCAR Antarctic Digital Database 
Table 1 Comparison of krill faecal pellet (FP) POC export at $100 \mathrm{~m}$ (this study) with literature estimates of total POC export

\begin{tabular}{|c|c|c|c|c|}
\hline $\begin{array}{l}\text { Data source/model } \\
\text { algorithm }\end{array}$ & $\begin{array}{l}\text { POC export flux in the } \\
\left.\text { MIZa (GT } C^{\text {yr }}{ }^{-1}\right)\end{array}$ & $\begin{array}{l}\text { Krill FP contribution to POC } \\
\text { export }^{b}(\%)\end{array}$ & $\begin{array}{l}\text { POC export flux south of } \\
60^{\circ} \mathrm{S}^{\mathrm{c}}\left(\mathrm{GT} \mathrm{C} \mathrm{yr}^{-1}\right)\end{array}$ & $\begin{array}{l}\text { Krill FP contribution to POC } \\
\text { export }^{\text {b }(\%)}\end{array}$ \\
\hline $\begin{array}{l}\text { This study -krill FPs only } \\
\text { Satellite-based estimates }\end{array}$ & \multicolumn{4}{|l|}{0.039} \\
\hline Carr, Henson & 0.076 & 51.5 & 0.101 & 38.5 \\
\hline Carr, Dunne & 0.122 & 32.0 & 0.152 & 25.6 \\
\hline Carr, Laws & 0.209 & 18.6 & 0.281 & 13.8 \\
\hline Marra, Henson & 0.082 & 47.2 & 0.104 & 37.4 \\
\hline Marra, Dunne & 0.137 & 28.4 & 0.160 & 24.3 \\
\hline Marra, Laws & 0.227 & 17.1 & 0.289 & 13.5 \\
\hline VGPM, Henson & 0.064 & 60.6 & 0.090 & 43.3 \\
\hline VGPM, Dunne & 0.103 & 37.6 & 0.135 & 28.8 \\
\hline VGPM, Laws & 0.177 & 21.9 & 0.250 & 15.5 \\
\hline \multicolumn{5}{|l|}{ POC export models } \\
\hline Primeau et al. $2013^{e, f}$ & & & 0.22 & 17.7 \\
\hline Schlitzer et al. $2002^{\mathrm{e}}$ & & & 1.00 & 3.9 \\
\hline MacCready et al. $2001^{e}$ & & & 0.31 & 12.5 \\
\hline \multicolumn{5}{|c|}{$\begin{array}{l}\text { aEstimates are for the productive season, October-March. For satellite-based estimates these are for the region south of the maximum ice extent during the productive period defined here (i.e. location of } \\
15 \% \text { sea ice concentration for period 1-13 October 1994-2014) } \\
\text { bPercentage contribution of our estimate of krill FP export flux (0.039 GT C yr }{ }^{-1} \text { ) to various total POC export estimates } \\
\text { cAnnual export for the region south of } 60^{\circ} \mathrm{S} \text {, with the exception of Schlitzer et al. (2002) and Primeau et al. (2013) which are for the regions south of } 50{ }^{\circ} \mathrm{S} \text { and } 55-60{ }^{\circ} \mathrm{S} \text {, respectively. } \\
\text { dNamed according to the input primary production and export (see methods) } \\
\text { eAnnual export } \\
\text { fExport at base of euphotic zone }(73.4 \mathrm{~m})\end{array}$} \\
\hline
\end{tabular}

contributions are conservative as our krill FP export flux is summed over the seasonal MIZ area, rather than south of $60^{\circ} \mathrm{S}$.

Energy budget calculations. We make independent estimates of krill FP flux at $100 \mathrm{~m}$ based on energy budget considerations. Taking estimates of circumpolar total gross krill production for

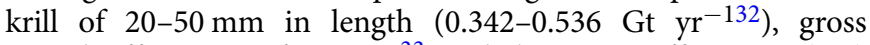
growth efficiencies of $20-30 \%{ }^{33}$, and absorption efficiencies (AE) of $0.42-0.94^{4}$, we estimate FPP rates of $0.01-0.25$ Gt C during our productive season (October-March), resulting in FP fluxes at 100 $\mathrm{m}$ of $0.007-0.150 \mathrm{Gt} \mathrm{C} \mathrm{yr}^{-1}$. This range is large, reflecting in particular the high range in $\mathrm{AE}$, related to feeding rates and food type. Constraining this range in $\mathrm{AE}$ to $0.75-0.85$ to reflect the more typical range of values reported ${ }^{3}$, we estimate FP fluxes at $100 \mathrm{~m}$ of $0.016-0.065 \mathrm{Gt} \mathrm{C} \mathrm{yr}^{-1}$.

\section{Discussion}

Taking available data in the literature, we have made first order estimates of the flux of krill FP in the MIZ of the Southern Ocean. Our model highlights that the seasonal export of krill FP is highest in the Scotia and Weddell Seas, a reflection of both high krill densities and the large extent of the MIZ in this region in austral summer. According to the KRILLBASE statistical model ${ }^{27,28}$, peak krill densities occur during 24 December-06 January and consequently, highest FP export fluxes (104 $\mathrm{mg} \mathrm{C} \mathrm{m}^{-2} \mathrm{~d}^{-1}$ averaged over the entire MIZ area, $\left.\mathrm{FP}_{100, \mathrm{MIZ}}\right)$ are predicted to occur during this period. For comparison, maximum fluxes of cylindrical FPs of $125.5 \mathrm{mg} \mathrm{C} \mathrm{m}^{-2} \mathrm{~d}^{-1}$ were observed in sediment traps at $170 \mathrm{~m}$ depth on the Western Antarctic Peninsula ${ }^{10}$ in February. This agrees well with our calculated maximum krill FP flux of 121 $\mathrm{mg} \mathrm{C} \mathrm{m}{ }^{-2} \mathrm{~d}^{-1}$ at $170 \mathrm{~m}$ in December in the region encompassing the Antarctic Peninsula $\left(-80\right.$ to $\left.-60^{\circ} \mathrm{E}\right)$, providing confidence in our model calculations.

We estimate that, over the productive season (October-March), the total export flux of krill FPs at $100 \mathrm{~m}$ in the $\operatorname{MIZ}\left(\mathrm{FP}_{100, \mathrm{SEA}}\right)$ is $0.039 \mathrm{GT} \mathrm{C}$ (Table 1$)$. This represents $17-61 \%$ of satellite-based estimates of total carbon export, highlighting that krill FP export may represent a significant proportion of estimated total POC export flux for the MIZ. The incorporation of POC export data collected via time-integrating methods, such as thorium (a radioactive tracer) as in the algorithms of Henson ${ }^{23}$ and Dunne ${ }^{25}$ (see methods), increases the chance that any carbon fluxes associated with ephemeral krill swarms are included in these satellite-based empirical algorithms. However, in situ POC export data are spatially limited and coverage in the MIZ is poor (Supplementary Figure 1); hence, these empirically derived estimates likely underrepresent the role of krill FP fluxes. If we assume that satellite-derived POC export estimates miss the contribution from krill FP in the MIZ modelled here, satellitederived POC export estimates represent only $62-85 \%$ of the total POC export in these regions.

We estimate that krill FP fluxes represent $12.5-17.7 \%$ of total carbon export (Table 1) based on the models of MacCready et al. (2001) and Primeau et al. (2013). Krill FP fluxes could therefore represent a significant fraction of Southern Ocean POC export flux and their mechanistic inclusion in global models could improve projections of future ocean carbon uptake. The relatively sparse data availability of POC flux estimates in the Southern Ocean, and the lack of the mechanistic inclusion of krill FP export may lead to underestimations of the contribution of the Southern Ocean to global export fluxes.

There are a number of uncertainties associated with our estimates due to necessary assumptions and the degree to which input parameters are constrained by available data. Firstly, we take the FPP rate from literature for a standard krill of $600 \mathrm{mg}$ fresh weight ${ }^{3}$. This is equivalent to a krill of length $34 \mathrm{~mm}$ based on the mass-to-length relationships calculated for the Scotia Sea in $2000^{34}$. Larger krill will produce larger FPs, which sink more rapidly and thus have a lower attenuation rate, where-as the opposite is true for smaller krill. The krill length of $34 \mathrm{~mm}$ sits at the low end of values reported in the field ${ }^{28,32,35,36}$, therefore our FPP rate is very conservative based on size.

Additionally, we assume a constant FPP rate throughout the day. It is likely that feeding rates, and thus egestion rates will change with food availability and season ${ }^{4}, 17$, but this process is not yet sufficiently constrained to be incorporated into our model. If krill were only egesting for $12 \mathrm{~h}$ a day then we would overestimate the flux of FPs by a factor of two. However, as the range in FP production estimates in the literature vary by over an order 
Table 2 Estimated FP export flux at $\mathbf{1 0 0} \mathbf{m}$ for various sensitivity runs for the period October-March

\begin{tabular}{|c|c|c|c|c|c|c|}
\hline Run & KRILLBASE data & MIZ data period & $\begin{array}{l}\text { FPP rate ( } \mathrm{mg} \mathrm{C} \\
\left.\text { ind }^{-1} d^{-1}\right)\end{array}$ & $\begin{array}{l}\text { Attenuation rate (Martin's b } \\
\text { value) }\end{array}$ & $\begin{array}{l}\text { Total FP } 100 \text { export } \\
\text { flux (GT C) }\end{array}$ & $\begin{array}{l}\% \text { of satellite } \\
\text { exporta }\end{array}$ \\
\hline A & All & 1994-2014 & 3.2 & 0.32 & 0.039 & $17.1-60.6$ \\
\hline$B$ & All & 1994-2014 & 0.67 & 0.32 & 0.008 & 3.7-13.1 \\
\hline C & All & 1994-2014 & 6.29 & 0.32 & 0.079 & $34.6-122.8$ \\
\hline D & All & 1994-2014 & 3.2 & $0.10^{b}$ & 0.055 & $24.3-86.3$ \\
\hline$E$ & All & 1994-2014 & 3.2 & $0.62^{b}$ & 0.024 & $10.5-37.3$ \\
\hline $\mathrm{F}$ & Unstandardised-median ${ }^{\mathrm{C}}$ & 1994-2014 & 3.2 & 0.32 & 0.002 & $0.9-3.1$ \\
\hline G & Unstandardised-90\% d & 1994-2014 & 3.2 & 0.32 & 0.053 & $23.9-82.1$ \\
\hline $\mathrm{H}$ & Unstandardised-mean ${ }^{\mathrm{e}}$ & 1994-2014 & 3.2 & 0.32 & 0.031 & $13.9-49.0$ \\
\hline \multicolumn{7}{|c|}{ 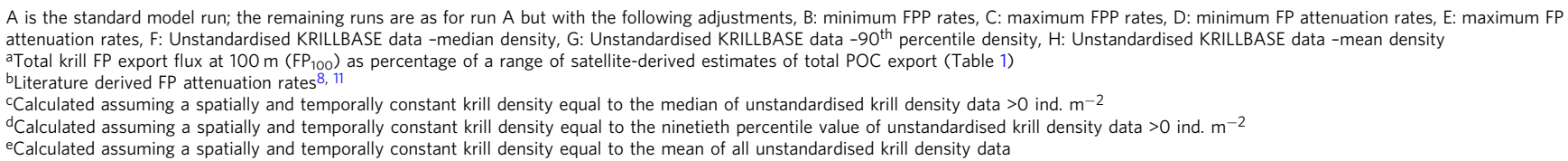 } \\
\hline
\end{tabular}

of magnitude, ${ }^{2-4,37,38}$, any diel variation is small in comparison. We recalculate total krill $\mathrm{FP}_{100}$ fluxes based on maximum (6.29 $\mathrm{mgC}$ ind. $\left.^{-1} \mathrm{~d}^{-1}\right)$ and minimum $\left(0.67 \mathrm{mgC}\right.$ ind. $\left.{ }^{-1} \mathrm{~d}^{-1}\right)$ FP production rates in the literature $3,4,37,38$. This results in seasonally integrated $\mathrm{FP}$ production $\left(\mathrm{FP}_{100, \mathrm{SEA}}\right)$ ranging between 0.008 and 0.079 GT C (sensitivity runs B and C, Table 2) highlighting the need for further studies on krill FPP rates to constrain this parameter or accurately model its variability (perhaps based on factors such as food availability). However, even with minimum rates of FPP, krill FP fluxes could still account for $4-13 \%$ of the total POC export flux based on satellite-derived estimates.

We also test the sensitivity of our model to the attenuation rate. The range in krill FP attenuation rates applicable to the Southern Ocean MIZ is $0.10-0.62^{2,8}, 9,11,12,20$. Using the upper and lower bounds of this range, we calculate $\mathrm{FP}_{100 \text {,SEA }}$ of 0.024 and 0.055 GT C respectively (sensitivity run D and E, Table 2 ). Even at the high end of literature derived attenuation rates, krill FP fluxes are $11-37 \%$ of the total POC export flux based on satellite-derived estimates, highlighting the potential magnitude of the missed POC flux. Additionally, the fact that our energy budget estimates of krill FP flux at $100 \mathrm{~m}\left(0.016-0.065 \mathrm{Gt} \mathrm{C} \mathrm{yr}^{-1}\right)$ encompass our best model estimate $\left(0.039 \mathrm{GT} \mathrm{C} \mathrm{yr}^{-1}\right)$, gives additional confidence in our results. Therefore, although data are limited, the available literature supports the notion that krill FPs make an important contribution to the POC export flux in marginal ice zones, particularly those with high krill abundances.

Krill density values have been derived from KRILLBASE ${ }^{27}$, in which net haul data have been standardised to a common sampling strategy to take into account varying levels of catch efficiency. However, as krill are able to escape nets, even with the most efficient net sampling strategy ${ }^{39}$, our estimates of krill density are likely conservative. To assess the impact of the use of standardised KRILLBASE densities (for the subset of KRILLBASE data used in our study), we recalculate the seasonal FP flux at $100 \mathrm{~m}$ based on krill densities of 1.1 and 29.8 ind. $\mathrm{m}^{-2}$ (sensitivity runs $F$ and G, Table 2). These are the median and $90^{\text {th }}$ percentile values for the unstandardised data, where densities are $>0$ ind. $\mathrm{m}^{-2}$, which we believe to be a fair representation of the possible range of the mean Southern Ocean krill density, whilst not being heavily biased by zero values or rare extreme values. This results in $\mathrm{FP}_{100, \mathrm{SEA}}$ of 0.002 and 0.053 GT C (Table 2) based on median and $90^{\text {th }}$ percentile values respectively, with the lower estimate likely to be at the extreme end. Taking the mean of all unstandardised krill density data (17.8 ind $\mathrm{m}^{-2}$ ) results in $\mathrm{FP}_{100 \text {,SEA }}$ of 0.031 GT C (sensitivity run $\mathrm{H}$ ) which is close to our estimate of 0.039 GT C for standardised data. The use of standardised KRILLBASE data does therefore not overly influence the conclusions drawn here. Since the marginal ice zone is harder to access and less well sampled than open waters, the KRILLBASE data are skewed towards regions of lower density, again increasing the likelihood that our estimates of krill FP flux are conservative.

Although our model results show that the estimated FP export flux in the MIZ is dominated by high krill density areas, this does not consider the effects of differences in zooplankton community structure, particularly in the abundance of microcopepods, many of which are coprorhexic or coprophagic. A number of studies have measured high retention of FPs in the euphotic zone, due most likely to copepod retention filters ${ }^{40,41}$, and currents generated by the swimming activities of both krill ${ }^{42}$ and copepods ${ }^{43}$ that could cause FP fragmentation, slow sinking rates and increased availability to smaller grazers such as dinoflagellates and ciliates ${ }^{44}$. Zooplankton community structure is therefore a key consideration when examining the degree to which sinking FPs are exported from the euphotic zone ${ }^{21}, 45-47$. Nevertheless, the importance of krill FPs in sediment traps (Supplementary Table 1$)^{2}, 8,9,11,12,20$, combined with evidence presented here, suggest that this retention filter could be short-circuited through a rain of large, fast sinking $\mathrm{FPs}^{4}, 9,47$, when krill densities (compared to microzooplankton grazers) are sufficiently high.

Our model of krill FP export flux represents a first-order estimation of the importance of krill for the export of carbon out of the euphotic zone of the MIZ of the Southern Ocean. We find krill FP export fluxes in the MIZ to be large which, if missed by current satellite-derived estimates of POC export (due to poor data availability in the MIZ), would add an additional $17-61 \%$ to POC export estimates for the Southern Ocean (Table 1), i.e. these empirical algorithms could underestimate POC export by $15-38 \%$. There is a need for increased spatial and temporal coverage of export data in MIZ regions to allow better representation of these important regions in empirically derived global estimates of POC export. Additionally, our work highlights that krill FP fluxes need to be mechanistically represented in global biogeochemical models to enable more accurate projections of the future Southern Ocean contribution to carbon export. As a site of deep water formation and also a region where deep nutrient-rich waters are exposed to the atmosphere ${ }^{48}$, the Southern Ocean is a key part of global biogeochemical cycles and contributes significantly to global export production ${ }^{30}$. It is therefore vital to quantify the efficiency of carbon transfer in the Southern Ocean as accurately as possible. Additionally our conclusions can be extended more globally, as the contribution to POC flux of FPs produced by other abundant swarming species, such as salps ${ }^{49,50}$, 
may also be under-represented in particle flux studies depending on the decomposition state of $\mathrm{FPs}^{51}$.

\section{Methods}

Krill faecal pellet production. Fortnightly climatologies of the extent of the marginal ice zone (MIZ) in Antarctica were calculated from daily long-term passive microwave sea ice concentration data from 1994-2014 from the National Snow and Ice Data Center (NSIDC) ${ }^{52}$. Median sea ice concentrations were calculated over the productive season (October-March ${ }^{53}$ ), and the MIZ region defined as $15-80 \%$ ice cover $^{18}$. The location and size of the MIZ can change rapidly ${ }^{52}$ and therefore using fortnightly MIZ data reduces uncertainties associated with short timescale variability in MIZ areal extent. Each fortnightly MIZ region was further divided into $5^{\circ}$ zonal cells $(k)$. For each fortnightly MIZ region, average krill densities in each cell were estimated using data from KRILLBASE; a database compiling 15,194 net hauls taken in the Southern Ocean between 1926-2016 ${ }^{27}$. Although KRILLBASE is the most comprehensive spatially-resolved dataset of Antarctic krill density, there are not sufficient data to cover each MIZ cell for every fortnight in the austral summer. Therefore, we take each spatially specific krill density data point from KRILLBASE and model the krill density at this location for each fortnightly period using an established model of krill density dynamics during the austral summer ${ }^{27,28}$. In this way, we obtain better coverage over the MIZ for each fortnight (Supplementary Figure 2). This model, in which krill density increases from October to a maximum in early January, before decreasing again until March, has been used to standardise KRILLBASE density estimates to a relatively efficient sampling strategy (to a nighttime RMT- 8 net haul to $200 \mathrm{~m}$ on 1 January $)^{27,28}$. We use the other elements of this standardisation, i.e. to a night-time RMT- 8 haul to $200 \mathrm{~m}$, to control for differences in net size, sampling depth, and time of day ${ }^{27,28}$, each of which may affect the degree of undersampling due to net avoidance or vertical distribution patterns. Despite standardisation to an efficient net sampling strategy, net avoid ance $^{39}$ means that even these standardised krill densities are likely an underestimate of true krill density. We used the haul and pooled stratified haul data, and excluded records representing survey means due to the potential for these survey means to cover more than one zonal cell. We also excluded data collected outside the austral spring and summer (October-March), or exclusively in deep strata. We converted each standardised krill density data point in KRILLBASE (with aforementioned exclusions) to a set of equivalent estimates for the mid-date of each fortnight using the standardisation model. We calculated $\bar{N}_{k, t}$, the average krill density in cell $k$ at time (fortnight) $t$, as the mean of all date-specific density estimates contained within the time-specific boundaries of cell $k$.

There are some caveats with our use of these data. Firstly, even though standardised to a single, relatively efficient sampling method, some have argued that issues of net mesh selection and avoidance will lead to underestimates of postlarval krill density ${ }^{39}$. This would lead to our estimates of krill faecal pellet production (FPP) being conservative. Secondly, we calculate krill densities in each MIZ zone by averaging all KRILLBASE data in that zone, creating a long-term average climatology of abundance. Therefore actual values in any given year will vary considerably about this mean ${ }^{28}$. Thirdly, our approach is sensitive to spatial differences in data availability (Supplementary Figure 2) with less reliable krill density estimates for sparsely sampled cells. Our use of the standardisation model to augment density estimates with data collected at other times of year was designed to reduce the impact of such spatial differences in data availability. However, this standardisation model does not represent any longitudinal differences in intra-annual krill dynamics, which could cause spatial differences in the accuracy of modelled dynamics. We also tested the sensitivity of our results to FPP rate and FP attenuation rate which demonstrate that our broad conclusions are robust (Table 2 ).

Fortnightly values of krill faecal pellet production (fpp) in each cell were calculated by multiplying mean krill densities (ind. $\mathrm{m}^{-2}$ ) by a krill FPP rate $(E)$ of $3.2 \mathrm{mg} \mathrm{C}$ ind. ${ }^{-1} \mathrm{~d}^{-1}$ from the literature ${ }^{2,3}$. The average FPP for the circumpolar $\mathrm{MIZ}$ area $\left(\mathrm{FPP}_{\mathrm{MIZ}}, \mathrm{mg} \mathrm{C} \mathrm{m}^{-2} \mathrm{~d}^{-1}\right)$ was calculated for each fortnightly period $(t)$ using the following equation:

$$
\mathrm{fpp}_{\mathrm{MIZ}, t}=\sum_{\mathrm{MIZ}}\left(\bar{N}_{k, t} \times E \times A_{k, t}\right) / A_{\mathrm{MIZ}, t} .
$$

Here, $A_{k, t}$ is the area of the $5^{\circ}$ cell bounded by the MIZ $\left(\mathrm{m}^{2}\right), A_{\mathrm{MIZ}, t}$ the total Southern Ocean MIZ area $\left(\mathrm{m}^{2}\right)$ for that fortnightly period excluding cells with no data, and $\bar{N}_{k, t}$ the mean krill density in that cell. Similarly, the total flux of FPs produced in the MIZ in each fortnightly period ( $\mathrm{fpp}_{\mathrm{TO}}, \mathrm{mg} \mathrm{C}$ ) was calculated using the following equation:

$$
\mathrm{fpp}_{\mathrm{TOT}, t}=\sum_{\mathrm{MIZ}}\left(\bar{N}_{k, t} \times E \times A_{k, t}\right) \times 14 \text { days. }
$$

Krill faecal pellet fluxes. We model the export flux of FPs at depth $z$ $\left(\mathrm{FP}_{z}, \mathrm{mg} \mathrm{C} \mathrm{m} \mathrm{m}^{-2} \mathrm{~d}^{-1}\right)$ in each cell based on literature estimates of krill FP attenuation $^{2}, 8,9,11,12,20$ appropriate to our study region. We apply the median attenuation rate $(b=0.32)$ to the FPP data in each cell, using the Martin curve ${ }^{14}$
We calculate for $z=100 \mathrm{~m}\left(\mathrm{FP}_{100}, \mathrm{mg} \mathrm{C} \mathrm{m}^{-2} \mathrm{~d}^{-1}\right)$ and, for comparison with a previous study ${ }^{10}$, for $z=170 \mathrm{~m}$.

$$
\mathrm{FP}_{z}=\mathrm{fpp} \times\left(z / z_{0}\right)^{-b}
$$

Here $z_{0}$ is the depth at which krill FPs are produced (taken as $20 \mathrm{~m}$, based on mean swarm depths of $18.9 \mathrm{~m}$ measured in the southern Scotia Sea in spring ${ }^{36}$ ). We model the flux of FPs over the MIZ region $\left(\mathrm{FP}_{100, \mathrm{MIZ}}, \mathrm{mg} \mathrm{C} \mathrm{m} \mathrm{m}^{-2} \mathrm{~d}^{-1}\right)$ and the total flux of FPs at $100 \mathrm{~m}$ in the MIZ for each fortnightly period $\left(\mathrm{FP}_{100, \mathrm{TOT}}, \mathrm{mg} \mathrm{C}\right)$,

$$
\begin{gathered}
\mathrm{FP}_{100, \mathrm{MIZ}, t}=\sum_{\mathrm{MIZ}}\left(\mathrm{FP}_{100, \mathrm{t}} \times \mathrm{A}_{\mathrm{k}, \mathrm{t}}\right) / A_{\mathrm{MIZ}, t}, \\
\mathrm{FP}_{100, \mathrm{TOT}, t}=\sum_{\text {MIZ }}\left(\mathrm{FP}_{100, t} \times A_{k, t}\right) \times 14 \text { days. }
\end{gathered}
$$

The total seasonal (October-March) $\mathrm{FP}_{100}$ flux $\left(\mathrm{FP}_{100, \mathrm{SEA}}\right.$, mg C) was calculated by summing the fluxes from each fortnightly period.

$$
\mathrm{FP}_{100, \mathrm{SEA}}=\sum_{\text {Mar }}^{\text {Oct }}\left(\mathrm{FP}_{100, \mathrm{TOT}}\right)
$$

Model comparisons. We compare our modelled krill FP export fluxes to a number of different modelled POC export fluxes at $100 \mathrm{~m}$ based on satellite-derived primary productivity estimates ${ }^{54-56}$ and algorithms for export production ${ }^{23-25}$ for the region south of the maximum ice extent during the productive period defined here (15\% sea ice concentration during period 1-13 October 1994-2014) (Table 1). These export estimates use primary productivity (PP) estimates derived from satellite chlorophyll-a via three main algorithms, referred to here as Carr ${ }^{56}$, Marra $^{55}$, and VGPM ${ }^{54}$. Satellite-based PP estimates have been shown to disagree with each other ${ }^{57}$ and likely underestimate PP in the Southern Ocean ${ }^{30,58}$. PP data are then used to calculate export production via three different algorithms, herein referred to as Laws ${ }^{24}$, Dunne ${ }^{25}$, and Henson ${ }^{23}$. The Laws algorithm utilises nitrate uptake data and f-ratio (the ratio of new production to total production); however the validity of f-ratio derived export estimates was recently questioned ${ }^{59}$ as they do not account for nitrification and therefore may overestimate export. In addition, only one of 11 samples used to derive the Laws algorithm is in the MIZ of the Antarctic. The Dunne algorithm uses estimates of export based on thorium, sediment traps, oxygen, and nitrate uptake data with 11 samples out of 122 in the MIZ. The Henson algorithm utilises solely thorium-derived particle export estimates, which represents time-integrated export estimated over the half life of thorium (24.1 days); 15 records out of 306 are in the MIZ. Because of its integration timescale, thorium-derived POC export estimates may better capture the passing of krill swarms and the associated high fluxes than sediment trap data. However, even if these high fluxes are captured by these time-integrated methods, or if in some MIZ regions large FP fluxes from krill swarms occur regularly enough to be captured by more short term particle flux methods, the limited number of data points in the MIZ used in the aforementioned algorithms (Supplementary Figure 1) means that the low attenuation rates occurring here will not be well represented. Only 5,9 , and $9 \%$ of data in the Henson, Laws, and Dunne algorithms, respectively, are from the MIZ of the Antarctic. This highlights the need for more observations in the MIZ to support regionally derived estimates of particle flux attenuation, and the incorporation of these into global export flux estimates.

In addition we compare our values of krill FP export to three biogeochemical models estimating POC export in the Southern Ocean (Table 1) ${ }^{29-31}$. Estimates of Primeau et al. (2013) are based on a data-assimilating (temperature, salinity, and radiocarbon distributions) model (horizontal resolution of $2 \times 2^{\circ}$ ) of ocean phosphate, calculated for their Antarctic zone ( south of $\left.55-60{ }^{\circ} \mathrm{S}\right)$ as defined by latitude of maximum Ekman divergence ${ }^{31}$. MacCready et al. (2001) use a diagnostic model (with zonally averaged $5^{\circ}$ bins) to calculate the physical fluxes in the surface nitrate budget, using a climatology of nitrate concentration (from historical CTD and bottle data primarily from WOCE and US JGOFS) to constrain nitrogen export ${ }^{29}$. Schlitzer et al. (2002) estimate carbon export south of $50^{\circ} \mathrm{S}$ from an inverse model based on hydrographic, nutrient (accounting for nitrification), oxygen, and carbon data, with horizontal resolution ranging from $5 \times 4^{\circ}$ longitude by latitude in open ocean areas to $2.5^{\circ}$ to $1^{\circ}$ in regions with narrow currents ${ }^{30}$. These regional models are not reliant on snapshot style POC flux measurements and provide better spatial coverage of the MIZ than satellite-based estimates.

Energy budget calculations. To obtain an independent estimate of krill FP fluxes, we take estimates of krill production and apply energy budget considerations. We

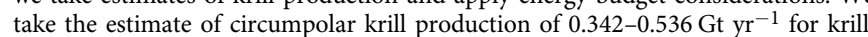
20-50 mm in length ${ }^{32}$, which is based on KRILLBASE krill densities and an empirical mode ${ }^{35}$ based on krill length, food concentration (from SeaWiFS satellite chlorophyll) and sea surface temperature (MODIS satellite). This is the production during a 4-month summer from 01 December to $31 \mathrm{March}^{32}$. Converting this wet mass production to units of carbon, we assume dry mass is $25 \%$ of wet mass ${ }^{32}$ and 
carbon content is $43 \%$ of dry mass 4 . Total carbon ingestion $\left(C_{\text {ing }}\right)$ was then estimated based on gross growth efficiencies of $20-30 \%{ }^{33}$, and $\mathrm{FP}$ production (fpp) calculated using absorption efficiencies $(a)$ of $0.42-0.94^{4}$ and the following relationship.

$$
C_{\text {ing }}=\mathrm{fpp} /(1-a)
$$

We also estimate fpp using a more constrained range in $a$ of $0.75-0.85^{3}$. As before, we use equation 3 (above) to estimate the krill FP flux at $100 \mathrm{~m}$, and sum over our productive season of (October-March).

\section{Data availability}

The KRILLBASE dataset analysed for this study is available online: A. Atkinson, S. L. Hill, E.A. Pakhomov, V. Siegel et al. (2016). KRILLBASE: A database of Antarctic krill and salp densities in the Southern Ocean, 1926 to 2016. [http://doi.org/brg8]. The marginal ice zone data were extracted from the National Snow and Ice Data Center, available here: Cavalieri, D. J., Parkinson, C. L., Gloersen, P. \& H. J. Zwally. Sea Ice Concentrations from Nimbus-7 SMMR and DMSP SSM/I-SSMIS Passive Microwave Data. Boulder, Colorado USA. NASA National Snow and Ice Data Center Distributed Active Archive Center (1996) [https://doi.org/10.5067/8GQ8LZQVL0VL]. The final data generated in this study are contained within Tables 1 and 2 in this manuscript, with supplementary data and figures as a Supplementary Information file.

Received: 3 August 2018 Accepted: 4 February 2019

Published online: 21 February 2019

\section{References}

1. Kwon, E. Y., Primeau, F. \& Sarmiento, J. L. The impact of remineralization depth on the air-sea carbon balance. Nat. Geosci. 2, 630-635 (2009).

2. Belcher, A. et al. The potential role of Antarctic krill faecal pellets in efficient carbon export at the marginal ice zone of the South Orkney Islands in spring. Polar Biol. 40, 2001-2013 (2017).

3. Clarke, A., Quetin, L. B. \& Ross, R. M. Laboratory and field estimates of the rate of faecal pellet production by Antarctic krill, Euphausia superba. Mar. Biol. 98, 557-563 (1988).

4. Atkinson, A., Schmidt, K., Fielding, S., Kawaguchi, S. \& Geissler, P. A. Variable food absorption by Antarctic krill: Relationships between diet, egestion rate and the composition and sinking rates of their fecal pellets. Deep Sea Res. Part II Top. Stud. Oceanogr. 59-60, 147-158 (2012).

5. Tarling, G. A. \& Fielding, S. in Biology and ecology of Antarctic krill 279-319 (ed. Siegel, V.) (Springer International Publishing, New York, 2016).

6. Murphy, E. J. et al. Spatial and temporal operation of the Scotia Sea ecosystem: a review of large-scale links in a krill centred food web. Philos. Trans. R. Soc. B Biol. Sci. 362, 113-148 (2007).

7. Passow, U. \& Carlson, C. A. The biological pump in a high $\mathrm{CO}_{2}$ world. Mar. Ecol. Prog. Ser. 470, 249-271 (2012).

8. Accornero, A., Manno, C., Esposito, F. \& Gambi, M. C. The vertical flux of particulate matter in the polynya of Terra Nova Bay. Part II. Biological components. Antarct. Sci. 15, 175-188 (2003).

9. Wefer, G., Fischer, G., Fuetterer, D. \& Gersonde, R. Seasonal particle flux in the Bransfieid Strait, Antarctica. Deep Sea Res. 35, 891-898 (1988).

10. Gleiber, M. R., Steinberg, D. K. \& Ducklow, H. W. Time series of vertical flux of zooplankton fecal pellets on the continental shelf of the western Antarctic Peninsula. Mar. Ecol. Prog. Ser. 471, 23-36 (2012).

11. Cadée, G. C., González, H. E. \& Schnack-Schiel, S. B. Krill diet affects faecal string settling. Polar Biol. 12, 75-80 (1992).

12. González, H. E. The distribution and abundance of krill faecal material and oval pellets in the Scotia and Weddell Seas (Antarctica) and their role in particle flux. Polar Biol. 12, 81-91 (1992).

13. Bodungen, vonB., Fischer, G., Nothing, E. M. \& Wefer, G. Sedimentation of krill faeces during spring development of phytoplankton in the Bransfield Strait, Antarctica. Mitt. aus dem Geol. Un. Paläontol. Inst. der Univ. Leipz. 62, 235-243 (1987).

14. Martin, J. H., Knauer, G. A., Karl, D. M. \& Broenkow, W. W. VERTEX: carbon cycling in the northeast Pacific. Deep Sea Res. Part I Oceanogr. Res. Pap. 34, 267-285 (1987).

15. Atkinson, A., Siegel, V., Pakhomov, E. A. \& Rothery, P. Long-term decline in krill stock and increase in salps within the Southern Ocean. Nature 432, 100-103 (2004).

16. Park, M. G., Yang, S. R., Kang, S. H., Chung, K. H. \& Shim, J. H. Phytoplankton biomass and primary production in the marginal ice zone of the northwestern Weddell Sea during austral summer. Polar Biol. 21, 251-261 (1999).
17. Meyer, B., Freier, U., Grimm, V., Groeneveld, J. \& Hunt, B. P. V. The winter pack-ice zone provides a sheltered but food-poor habitat for larval Antarctic krill. Nat. Ecol. Evol. 1, 1853-1861 (2017).

18. Stroeve, J. C., Jenouvrier, S., Campbell, G. G., Barbraud, C. \& Delord, K. Mapping and Assessing Variability in the Antarctic Marginal Ice Zone, the Pack Ice and Coastal Polynyas. Cryosph. Discuss. 1-40 (2016).

19. Schmidt, K. et al. Do pelagic grazers benefit from sea ice? Insights from the Antarctic sea ice proxy IPSO25. Biogeosciences 15, 1987-2006 (2018).

20. Cavan, E. L. et al. Attenuation of particulate organic carbon flux in the Scotia Sea, Southern Ocean, controlled by zooplankton fecal pellets. Geophys. Res. Lett. 42, 821-830 (2015).

21. Belcher, A. et al. The role of particle associated microbes in remineralization of fecal pellets in the upper mesopelagic of the Scotia Sea, Antarctica. Limnol. Oceanogr. 61, 1049-1064 (2016)

22. Marr, J. W. S. The natural history and geography of the Antarctic krill (Euphausia superba Dana). Discov. Rep. 32, 33-464 (1962).

23. Henson, S. A. et al. A reduced estimate of the strength of the ocean's biological carbon pump. Geophys. Res. Lett. 38, L04606 (2011).

24. Laws, E. A., Falkowski, P. G., Smith, W. O., Hugh, D. \& Mccarthy, J. J. Temperature effects on export production in the open ocean. Glob. Biogeochem. Cycles 14, 1231-1246 (2000).

25. Dunne, J. P., Armstrong, R. A., Gnanadesikan, A. \& Sarmiento, J. L. Empirical and mechanistic models for the particle export ratio. Global. Biogeochem. Cycles 19, GB4026 (2005).

26. Fischer, G. et al. Seasonal variability of particle flux in the Weddell Sea and its relation to ice cover. Nature 335, 426-428 (1988).

27. Atkinson, A. et al. KRILLBASE: a circumpolar database of Antarctic krill and salp numerical densities, 1926-2016. Earth Syst. Sci. Data 9, 193-210 (2017).

28. Atkinson, A. et al. Krill (Euphausia superba) distribution contracts southward during rapid regional warming. Nat. Clim. Chang. 9, 142-147 (2019).

29. MacCready, P. \& Quay, P. Biological export flux in the Southern Ocean estimated from a climatological nitrate budget. Deep. Res. Part II Top. Stud. Oceanogr. 48, 4299-4322 (2001).

30. Schlitzer, R. Carbon export fluxes in the Southern Ocean: results from inverse modeling and comparison with satellite-based estimates. Deep Sea Res. Part II Top. Stud. Oceanogr. 49, 1623-1644 (2002).

31. Primeau, F. W., Holzer, M. \& DeVries, T. Southern Ocean nutrient trapping and the efficiency of the biological pump. J. Geophys. Res. 118, 2547-2564 (2013).

32. Atkinson, A., Siegel, V., Pakhomov, E. A., Jessopp, M. J. \& Loeb, V. A reappraisal of the total biomass and annual production of Antarctic krill. Deep. Res. Part I Oceanogr. Res. Pap. 56, 727-740 (2009).

33. Straile, D. Gross growth efficiencies of protozoan and metazoan zooplankton and their dependence on predator-prey weight ratio, and taxonomic group. Limnol. Oceanogr. 42, 1375-1385 (1997).

34. Hewitt, R. P. et al. Biomass of Antarctic krill in the Scotia Sea in January/ February 2000 and its use in revising an estimate of precautionary yield. Deep Sea Res. Part II Top. Stud. Oceanogr. 51, 1215-1236 (2004).

35. Atkinson, A. et al. Natural growth rates in Antarctic krill (Euphausia superba): II. Predictive models based on food, temperature, body length, sex, and maturity stage. Limnol. Oceanogr. 51, 973-987 (2006).

36. Fielding, S., Watkins, J. L., Collins, M. A., Enderlein, P. \& Venables, H. J. Acoustic determination of the distribution of fish and krill across the Scotia Sea in spring 2006, summer 2008 and autumn 2009. Deep. Res. Part II 59-60, 173-188 (2012).

37. Pakhomov, E. A., Perissinotto, R., Froneman, P. W. \& Miller, D. G. M. Energetics and feeding dynamics of Euphausia superba in the South Georgia region during the summer of 1994. J. Plankton Res. 19, 399-423 (1997).

38. Nordhausen, W. \& Huntley, M. E. RACER: Carbon egestion rates of Euphausia superba. Antarct. J. U. S. 25, 161-162 (1990).

39. Everson, I. \& Bone, D. G. The effectiveness of the RMT8 system for sampling krill (Euphausia superba) swarms. Polar Biol. 6, 83-90 (1986).

40. Wexels-Riser, C., Wassmann, P., Olli, K. \& Arashkevich, E. Production, retention and export of zooplankton faecal pellets on and off the Iberian shelf, north-west Spain. Prog. Oceanogr. 51, 423-441 (2001).

41. Wexels Riser, C., Reigstad, M., Wassmann, P., Arashkevich, E. \& FalkPetersen, S. Export or retention? Copepod abundance, faecal pellet production and vertical flux in the marginal ice zone through snap shots from the northern Barents Sea. Polar Biol. 30, 719-730 (2007).

42. Dilling, L. \& Alldredge, A. L. Fragmentation of marine snow by swimming macrozooplankton: a new process impacting carbon cycling in the sea. Deep. Res. Part I Oceanogr. Res. Pap. 47, 1227-1245 (2000).

43. Poulsen, L. \& Kiørboe, T. Coprophagy and coprorhexy in the copepods Acartia tonsa and Temora longicornis: clearance rates and feeding behaviour. Mar. Ecol. Prog. Ser. 299, 217-227 (2005).

44. Poulsen, L. \& Iversen, M. H. Degradation of copepod fecal pellets: key role of protozooplankton. Mar. Ecol. Prog. Ser. 367, 1-13 (2008). 
45. Wassmann, P., Erik, J. \& Tselepides, A. Vertical flux of faecal pellets and microplankton on the shelf of the oligotrophic Cretan Sea (NE Mediterranean Sea). Prog. Oceanogr. 46, 241-258 (2000).

46. Viitasalo, M., Rosenberg, M., Heiskanen, A.-S. \& Koski, M. Sedimentation of copepod fecal material in the coastal northern Baltic Sea: Where did all the pellets go? Limnol. Ocean. 44, 1388-1399 (1999).

47. Wassmann, P., Olli, K., Wexels Riser, C. \& Svensen, C. in Marine science frontiers for europe 279-287 (eds. Wefer, G., Lamy, F. \& Mantoura, F.) (Springer Verlag, Berlin, Heidelberg, 2002).

48. Toggweiler, J. R. The Ocean's overturning circulation. Phys. Today 47, 45-50 (1994).

49. Stone, J. P. \& Steinberg, D. K. Salp contributions to vertical carbon flux in the Sargasso Sea. Deep. Res. Part I Oceanogr. Res. Pap. 113, 90-100 (2016).

50. Smith, K. L. Jr. et al. Large salp bloom export from the upper ocean and benthic community response in the abyssal northeast Pacific: day to week resolution. Limnol. Oceanogr. 59, 745-757 (2014).

51. Iversen, M. H. et al. Sinkers or floaters? Contribution from salp pellets to the export fl ux during a large bloom event in the Southern Ocean. Deep Sea Res. Part II Top. Stud. Oceanogr. 138, 116-125 (2017).

52. Cavalieri, D. J., Parkinson, C. L., Gloersen, P. \& Zwally, H. Sea ice concentrations from Nimbus-7 SMMR and DMSP SSM/I-SSMIS passive microwave data. NASA Natl. Snow Ice Data Center Distrib. Active Arch. Center https://doi.org/10.5067/8GQ8LZQVL0VL (1996).

53. Tarling, G. A. \& Johnson, M. L. Satiation gives krill that sinking feeling. Curr. Biol. 16, 83-84 (2001).

54. Behrenfeld, M. J. \& Falkowski, P. G. Photosynthetic rates derived from satellite-based chlorophyll concentration. Limnol. Oceanogr. 42, 1-20 (1997).

55. Marra, J., Ho, C. \& Trees, C. C. An alternative algorithm for the calculation of primary productivity from remote sensing data. LDEO Tech. Rep. 2003-1 (Lamont Doherty Earth Observatory, New York, 2003).

56. Carr, M. Estimation of potential productivity in Eastern Boundary Currents using remote sensing. Deep Sea Res. Part II Top. Stud. Oceanogr. 49, 59-80 (2002).

57. Carr, M. et al. A comparison of global estimates of marine primary production from ocean color. Deep Sea Res. Part I Oceanogr. Res. Pap. 53, 741-770 (2006).

58. Johnson, R., Strutton, P. G., Wright, S. W., McMinn, A. \& Meiners, K. M. Three improved satellite chlorophyll algorithms for the Southern Ocean. J. Geophys. Res. Ocean. 118, 3694-3703 (2013).

59. Yool, A., Martin, A. P., Ferna, C. \& Clark, D. R. The significance of nitrification for oceanic new production. Nature 447, 999-1002 (2007).

\section{Acknowledgements}

We would like to thank all the crew and scientists involved in collecting the decades of krill density data used to create the KRILLBASE database. Anna Belcher, Geraint A.

Tarling, Clara Manno, Sally E. Thorpe, and Simeon L. Hill were supported by the Ocean

Ecosystems programme at British Antarctic Survey and a Large Grant from the UK
Natural Environment Research Council (NE/M020835/1). Stephanie Henson was supported by a European Research Council Consolidator grant (GOCART, agreement number 724416). Angus Atkinson was funded through the UK Natural Environment Research Council through its National Capability grant number (NE/R015953/1). Additionally Anna Belcher was supported by a PhD studentship from the University of Southampton.

\section{Author contributions}

A.B., G.A.T., and C.M. derived early hypotheses, A.B. and G.A.T. designed the analytica approach and A.B. analysed results. P.F., L.I., and S.E.T. provided MIZ data analysis support. A.A. helped with KRILLBASE and energy budget calculations. S.A.H. conducted model comparisons and S.L.H. estimated fortnightly krill densities. A.B. wrote the manuscript with contributions by all co-authors.

\section{Additional information}

Supplementary Information accompanies this paper at https://doi.org/10.1038/s41467019-08847-1.

Competing interests: The authors declare no competing interests.

Reprints and permission information is available online at http://npg.nature.com/ reprintsandpermissions/

Journal peer review information: Nature Communications thanks Francois Primeau and Philipp Assmy for their contribution to the peer review of this work. Peer reviewer reports are available.

Publisher's note: Springer Nature remains neutral with regard to jurisdictional claims in published maps and institutional affiliations.

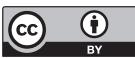

Open Access This article is licensed under a Creative Commons Attribution 4.0 International License, which permits use, sharing, adaptation, distribution and reproduction in any medium or format, as long as you give appropriate credit to the original author(s) and the source, provide a link to the Creative Commons license, and indicate if changes were made. The images or other third party material in this article are included in the article's Creative Commons license, unless indicated otherwise in a credit line to the material. If material is not included in the article's Creative Commons license and your intended use is not permitted by statutory regulation or exceeds the permitted use, you will need to obtain permission directly from the copyright holder. To view a copy of this license, visit http://creativecommons.org/ licenses/by/4.0/.

(C) The Author(s) 2019 